ISSN 0258-7122

Bangladesh J. Agril. Res. 37(2): 195-205, June 2012

\title{
EFFECT OF STORAGE CONTAINERS AND STORAGE PERIODS ON THE SEED QUALITY OF FRENCH BEAN (Phaseolus vulgaris)
}

\author{
K. M. KHALEQUZZAMAN ${ }^{1}$, M. M. RASHID ${ }^{2}$ \\ M. A. $\operatorname{HASAN}^{3}$ AND M. M. A. REZA ${ }^{4}$
}

\begin{abstract}
The experiment was conducted in the Laboratory, Department of Plant Pathology, HSTU, Dinajpur during April - July 2010 to know the effect of abiotic and biotic factors, storage periods and storage containers on the seed quality of French bean. Tin container showed the highest germination, normal seedlings and vigour index which were followed by polythene bag, where Gunny bag showed the lowest germination, normal seedlings and vigour index upto 60 days after storage. The highest 1000-seed weight, moisture content, abnormal seedlings, seed rot and incidence of the Fusarium oxysporum were recorded in Gunny bag, where the lowest of these parameters were recorded in Tin container. Seed colour of Tin container were more or less same as initial colour, but seeds of Gunny bag were changed into fade or brown colour at 60 days after storage. Moisture content, 1000-seed weight, abnormal seedlings, seed rot, fungi association were increased, but germination and normal seedlings were decreased with the increase of storage periods. Among the three containers, Tin container was the best and the Gunny bag was the worst storage containers upto 60 days of storage for French bean seed.
\end{abstract}

Keywords: Storage containers, storage periods, seed quality, french bean.

\section{Introduction}

French bean (Phaseolus vulgaris, $2 \mathrm{n}=22$ ) is most widely cultivated of all beans in temperate regions, and widely cultivated in semitropical regions. It is the second largest legume producing vegetable in the world (Rashid, 1999). It is also known as Bush bean, Common bean, Kidney bean, Dry bean, Haricot bean, Snap bean, Navy bean, String bean, Pinto bean, White bean, and Master bean in different parts of the world (McFadden and Hall, 1987). In Bangladesh, the crop is known in different names in different locations e.g. in Sylhet it is known as "Farashi Ori" and "Farash Choi" in Chittagong and in most parts of the country "Jhar Sheem". It is a highly nutritious and protein rich legume vegetable. It is used as tender vegetable, shelled green beans, dry bean and pulses which is highly nutritious. French bean is cultivated popularly in Chittagong, Sylhet,

\footnotetext{
${ }^{1}$ Senior Scientific Officer, Bangladesh Agricultural Research institute (BARI), Ishurdi, Pabna, ${ }^{2}$ Professor, Department of Plant Pathology, Hajee Mohammad Danesh Science \& Technology University (HSTU), Dinajpur, ${ }^{3}$ Associate Professor, Department of Agronomy, HSTU, Dinajpur, ${ }^{4}$ Senior Scientific Officer, WRC, BARI, Nashipur, Dinajpur, Bangladesh.
} 
North Bengal, Hill tracts and also many other places of Bangladesh. Now a days, it is considered as one of the most important exporting vegetables of Bangladesh to earn foreign currency and is being exported by Horticultural Export Development Foundation (HORTEX), Dhaka, Bangladesh (Anonymous, 2002). It is an important crop, which is capable of fixing and utilizing atmospheric nitrogen through symbiotic relationship with Rhizobium at the root nodule of the crop.

French bean is now being cultivated at 0.2 thousand hectares in Bangladesh. But area of the crop is being increased day by day for its popularity. Requirement of quality seeds of French bean is $10.5 \mathrm{t} / \mathrm{ha}$, but the supply of the seeds is $6.2 \mathrm{t} / \mathrm{ha}$ (Rakhi, 2000). The average yield of French bean is very low in Bangladesh (Rashid, 1993). There are many factors that can narrow down the gap between potential and farm level yield. Among them, use of quality seed is the most important one (Ahmad, 2001), as quality seeds ensure better germination as well as better yield. Using of good quality seed can contribute to increase yield as high as 30\% keeping the other factors of production as constant (BARI, 1993). Ten to fifteen percent production was found reduced due to use of poor quality seed (Huda, 2001). Major part of seed quality deteriorates at the time of storage in our country. Most of the farmers do not know how to preserve seed. They store their seeds as they store their food grain. Although seed quality is governed by genetic make-up, but commonly the quality of seeds is deteriorated during storage period. Seed storage and retention of seed viability always an important consideration in agricultural practice. Poor storage conditions greatly affect seed vigor (Heydecker, 1979). The deterioration rate depends on storage condition that is temperature, relative humidity, seed moisture contents, storage container types, etc. Types of container also regulate temperature, relative humidity, and seed moisture contents. High temperature, relative humidity, and moisture in the storage environment appear to be principle factors involved in deterioration of seed quality. As a result, seed health has been found to be influenced by the seed quality (Fakir et al., 1989). According to above background, no research work in the discipline on storage of French bean seeds in different containers for different storage periods in Bangladesh has so far been conducted. So, the present study was undertaken to determine the effect of abiotic and biotic factors, different storage periods and containers on the seed quality of French bean.

\section{Materials and Method}

The experiment was conducted in the Laboratory, Department of Plant Pathology, Hajee Mohammad Danesh Science and Technology University (HSTU), Dinajpur, Bangladesht during April - July 2010. French bean seeds (var. BARI French bean 1) were collected from Plant Genetic Resource Centre (PGRC),

RARS, Ishurdi, Pabna. The experiment was laid out in Completely Randomized 
Design (CRD) with four replications. Three storage containers- Tin container, Polythene bag and Gunny bag; and five storage periods - before storage, 15 days of storage, 30 days of storage, 45 days of storage, and 60 days of storage were used in this experiment. Seeds were stored at room temperature and relative humidity (RH) up to 60 days. The Tin container was covered tightly, and the Polythene bag and Gunny bag were tight with rope. Seed samples were taken randomly from each storage container were tested at five times i.e. five storage periods noted above.

Moisture content was determined at every 15 days during experimental period. Moisture content was determined by using high constant temperature oven method $\left(125-130^{\circ} \mathrm{C}, 2 \mathrm{hr}\right)$ following International Rules for Seed Testing (ISTA, 1999).

Four hundred seeds were tested for germination from each container for every storage period in both the petridishes and the pots as per the rules of ISTA (1999). In petridish, moist blotter paper was used as germination media. Adequate moisture level was maintained in the germination media. In pot, germination test was conducted using sand as substratum. The sand was sieved to discard particles bigger than $0.8 \mathrm{~mm}$ and smaller than $0.05 \mathrm{~mm}$ in diameter. For every test new sand was used. Seed was placed on a uniform layer of moist sand and then covered to a depth of $10 \mathrm{~mm}$ with sand, which was left loose. The pot was irrigated at every odd day. After 5 days and 8 days, germination percentage was determined. Data on normal and abnormal seedlings, and shoot and root length were recorded from pot experiment. The normal seedlings and abnormal seedlings were classified according to the prescribed rules given by ISTA, 1999.

For vigour index or seedling vigour data was recorded on germination up to 15 days of sowing. Then root length and shoot length were measured from seedlings of pots for calculating vigour index. Vigour index (VI) was calculated by using the formula of Baki and Anderson (1973) as shown below:

Vigour index (VI) = Germination (\%) X (Mean shoot length + mean root length)

To detect the seed borne pathogens associated with the seeds in samples, the blotter method was used. The seeds in the petridish were inoculated at $20 \pm 2^{0} \mathrm{C}$ under alternating cycles of 12 hours near ultraviolet (NUV) light at darkness for 8 days. Each individual incubated seed was observed under Stereo-binocular microscope at $16 \mathrm{X}$ and $25 \mathrm{X}$ magnifications in order to record the incidence of seed borne fungi. Most of the associated pathogens were detected by observing their growth characters on the incubated seeds on blotter paper. For proper identification of fungi temporary slides were prepared from the fungal colony and observed under compound microscope and fungi were identified following the key outlined by Booth (1971) and Singh (1982). Insects and insect bitten seeds were observed for counting at the starting of experiment and at an interval 
of 15 days up to 60 days of storage. The data were recorded on 1000-seed weight, moisture content, germination, seed rotten, normal, and abnormal seedlings, vigour index, seed colour and prevalence of fungi and insect. The recorded data were analyzed statistically to find out the level of significance and the variations among the treatments were compared as per Duncan's New Multiple Range Test (DMRT) (Gomez and Gomez, 1984).

\section{Results and Discussion}

Effect of containers and storage periods on 1000-seed weight and moisture content of French bean

Results of containers and storage periods on 1000-seed weight and moisture content of French bean are presented in Table 1. 1000-seed weight was 175.70 $\mathrm{g}$ for all containers immediately before storage. 1000-seed weight was significantly different from container to container for all storage periods and the weight increased with the increase in storage period. The maximum 1000seed weight (178.60, 182.80, 187.63, and $193.16 \mathrm{~g}$ ) was recorded in Gunny bag and the lowest 1000-seed weight $(176.30,177.50,178.70$, and $180.97 \mathrm{~g})$ was recorded in Tin container at 15, 30, 45, and 60 days after storage (DAS), respectively, which was not statistically different to those in Polythene bag for identical storage period. Initial moisture content was $13.1 \%$ for all containers before storage. Storage container showed significant effect on moisture content which increased with the increase in storage period. Seeds in Gunny bag gave the highest moisture (15.00, 17.10, 20.33 and 24.25\%) and Tin container resulted the lowest moisture (13.50, 14.33, 15.99 and 16.59\%) at 15, 30, 45 and 60 DAS, respectively, which was statistically at par with those in Polythene bag except 15 DAS.

Table 1. Effect of containers and storage periods on 1000 seed weight and moisture content of French bean.

\begin{tabular}{|c|c|c|c|c|c|c|c|c|c|c|}
\hline \multirow{2}{*}{ Containers } & \multicolumn{5}{|c|}{ 1000-seed weight (g) at } & \multicolumn{5}{|c|}{ Moisture content (\%) at } \\
\hline & $\begin{array}{l}\text { Before } \\
\text { storage }\end{array}$ & 15 DAS & AS & 45 DAS & AS & & $\begin{array}{c}15 \\
\text { DAS }\end{array}$ & $\begin{array}{c}30 \\
\text { DAS }\end{array}$ & $\begin{array}{c}45 \\
\text { DAS }\end{array}$ & $\begin{array}{c}60 \\
\text { DAS }\end{array}$ \\
\hline & & $176.30 \mathrm{c}$ & & & & 10 & $0 \mathrm{c}$ & $33 \mathrm{~b}$ & $15.99 \mathrm{~b}$ & 16 \\
\hline $\begin{array}{l}\text { Polyt } \\
\text { bag }\end{array}$ & 175.70 & $177.20 \mathrm{bc}$ & 17 & & & 13.10 & $13.90 \mathrm{~b}$ & $15.99 \mathrm{~b}$ & $17.00 \mathrm{~b}$ & 19.8 \\
\hline Gunny bag & 175.70 & $178.60 \mathrm{a}$ & $182.80 \mathrm{a}$ & $187.63 \mathrm{a}$ & $193.16 a$ & 13.10 & $15.00 \mathrm{a}$ & $17.10 \mathrm{a}$ & 20.33 a & $24.25 \mathrm{a}$ \\
\hline
\end{tabular}

Means bearing same letter(s) within same column do not differ significantly at $1 \%$ level of significance

DAS = Days after storage 


\section{Effect of containers and storage periods on germination and seed rot of French bean seed}

Results of containers and storage periods on germination and seed rot of French bean are presented in Table 2. Initial germination was $95.00 \%$ for all containers before storage. The effect of storage containers on germination of French bean seed was statistically significant for all storage periods. Germination percentage decreased with the increase of storage period. The highest germination (94.50, 93.05, 90.50, and 87.85\%) was recorded for seeds in Tin container, which was not significantly statistically different to those in Polythene bag except those after 15 DAS and the lowest germination (90.50, 84.00, 79.49, and 70.11\%) was recorded in Gunny bag at 15, 30, 45, and 60 days after storage (DAS), respectively. Initial seed rot was $5.00 \%$ for all containers before storage. Significant difference on the seed rot of French bean was observed among the storage containers for all storage periods. Seed rot increased with the increase in storage period. Gunny bag gave the highest seed rot $(9.50,16.00,20.51$, and $29.89 \%$ ) and Tin container gave the lowest seed rot (5.50, 6.95, 9.50, and $12.15 \%)$ at $15,30,45$ and 60 DAS, respectively which was statistically identical to Polythene bag except 15 DAS.

Table 2. Effect of containers and storage periods on germination and seed rot of French bean seed.

\begin{tabular}{|c|c|c|c|c|c|c|c|c|c|c|}
\hline \multirow[b]{2}{*}{ Containers } & \multicolumn{5}{|c|}{ Germination (\%) at } & \multicolumn{5}{|c|}{ Seed rot (\%) at } \\
\hline & $\begin{array}{l}\text { Before } \\
\text { storage }\end{array}$ & $\begin{array}{c}15 \\
\text { DAS }\end{array}$ & $\begin{array}{c}30 \\
\text { DAS }\end{array}$ & $\begin{array}{c}45 \\
\text { DAS }\end{array}$ & $\begin{array}{c}60 \\
\text { DAS }\end{array}$ & $\begin{array}{l}\text { Before } \\
\text { storage }\end{array}$ & $\begin{array}{c}15 \\
\text { DAS }\end{array}$ & $\begin{array}{c}30 \\
\text { DAS }\end{array}$ & $\begin{array}{c}45 \\
\text { DAS }\end{array}$ & $\begin{array}{c}60 \\
\text { DAS }\end{array}$ \\
\hline $\begin{array}{l}\text { Tin } \\
\text { conta }\end{array}$ & 95.00 & $94.50 \mathrm{a}$ & $93.05 \mathrm{a}$ & $90.50 \mathrm{a}$ & 87.85 a & 5.00 & $5.50 \mathrm{c}$ & $6.95 \mathrm{~b}$ & $9.50 \mathrm{~b}$ & $12.15 b$ \\
\hline $\begin{array}{l}\text { Polythene } \\
\text { bag }\end{array}$ & 95.00 & $92.30 \mathrm{~b}$ & $90.50 \mathrm{a}$ & $87.30 \mathrm{a}$ & 83.7 & 5.00 & $7.70 \mathrm{~b}$ & $9.50 \mathrm{~b}$ & $12.70 \mathrm{~b}$ & 16.3 \\
\hline $\begin{array}{l}\text { Gunny } \\
\text { bag }\end{array}$ & 95.00 & $90.50 \mathrm{c}$ & $84.00 \mathrm{~b}$ & $79.49 \mathrm{~b}$ & $70.11 b$ & 5.00 & $9.50 \mathrm{a}$ & $16.00 \mathrm{a}$ & $20.51 \mathrm{a}$ & 29.89 a \\
\hline
\end{tabular}

Means bearing same letter(s) within same column do not differ significantly at $1 \%$ level of significance

DAS $=$ Days after storage

\section{Effect of containers and storage periods on normal and abnormal seedling of French bean}

Results of containers and storage periods on normal and abnormal seedling of French bean are presented in Table 3. Initial normal seedling was $90.00 \%$ for all containers before storage. Normal seedling of French bean was significantly affected by containers for all storage periods and decreased with the increase of storage period in a given container. The highest normal seedlings (88.50 and 84.65\%) was recorded in Tin container which was statistically similar to 
Polythene bag and the lowest normal seedling (81.49 and 74.55\%) was recorded in Gunny bag at 30 and 60 DAS, respectively. Initial abnormal seedling was $10.00 \%$ for all containers before storage. Storage containers exhibited significant effect on the abnormal seedling of French bean for all storage periods. Abnormal seedling was increased with the increase of storage period. The highest abnormal seedling (18.51 and 25.45\%) was recorded in Gunny bag and the lowest abnormal seedling (11.50 and 15.35\%) was recorded in Tin container which was statistically identical to Polythene bag at 30 and 60 DAS, respectively.

Table 3. Effect of containers and storage periods on normal and abnormal seedling of French bean.

\begin{tabular}{l|c|c|c|c|c|c}
\hline \multirow{2}{*}{ Containers } & \multicolumn{3}{|c|}{ Normal seedling (\%) at } & \multicolumn{3}{c}{ Abnormal seedling (\%) at } \\
\cline { 2 - 7 } & $\begin{array}{c}\text { Before } \\
\text { storage }\end{array}$ & 30 DAS & 60 DAS & $\begin{array}{c}\text { Before } \\
\text { storage }\end{array}$ & 30 DAS & 60 DAS \\
\hline Tin container & 90.00 & $88.50 \mathrm{a}$ & $84.65 \mathrm{a}$ & 10.00 & $11.50 \mathrm{~b}$ & $15.35 \mathrm{~b}$ \\
Polythene bag & 90.00 & $86.86 \mathrm{a}$ & $81.14 \mathrm{a}$ & 10.00 & $13.14 \mathrm{~b}$ & $18.86 \mathrm{~b}$ \\
Gunny bag & 90.00 & $81.49 \mathrm{~b}$ & $74.55 \mathrm{~b}$ & 10.00 & $18.51 \mathrm{a}$ & $25.45 \mathrm{a}$ \\
\hline
\end{tabular}

Means bearing same letter(s) within same column do not differ significantly at $1 \%$ level of significance

DAS = Days after storage

Effect of containers and storage periods on vigour index or seedling vigour and incidence (\%) of Fusarium oxysporum of French bean

Results of containers and storage periods on vigour index or seedling vigour and incidence (\%) of Fusarium oxysporum of French bean are presented in Table 4. Initial vigour index was 2517.50 for all containers before storage. Storage containers had significant effect on vigour index. Vigour index was decreased with the increase of storage period. The highest vigour index (2327.71) was obtained from Tin container which was statistically similar to Polythene bag (2117.40) and the lowest vigour index (1837.43) was obtained from Gunny bag at 30 DAS. Incase of 60 DAS, vigour index ranged from 1393.95 to 2101.54, while the highest and lowest were recorded in Tin container and Gunny bag, respectively. Initial incidence of $F$. oxysporum was $12.00 \%$ for all containers before storage. Storage containers had significant effect on incidence of $F$. oxysporum for all storage periods. Incidence of $F$. oxysporum was increased with the increase of storage period. The highest incidence of $F$. oxysporum (18.06 and 26.69\%) was observed in Gunny bag and the lowest incidence (14.59 and $17.88 \%$ ) was observed in Tin container which was followed by Polythene bag at 30 and 60 DAS, respectively. 
Table 4. Effect of containers and storage periods on vigour index and incidence (\%) of Fusarium oxysporum of French bean.

\begin{tabular}{l|c|c|c|c|c|c}
\hline \multirow{2}{*}{ Containers } & \multicolumn{3}{c|}{ Vigour index at } & \multicolumn{3}{c}{$\begin{array}{c}\text { Incidence (\%) of Fusarium } \\
\text { oxysporum at }\end{array}$} \\
\cline { 2 - 8 } & $\begin{array}{l}\text { Before } \\
\text { storage }\end{array}$ & 30 DAS & 60 DAS & $\begin{array}{c}\text { Before } \\
\text { storage }\end{array}$ & 30 DAS & 60 DAS \\
\hline $\begin{array}{l}\text { Tin container } \\
\begin{array}{l}\text { Polythene } \\
\text { bag }\end{array}\end{array} 2517.50$ & $2327.71 \mathrm{a}$ & $2101.54 \mathrm{a}$ & 12.00 & $14.59 \mathrm{~b}$ & $17.88 \mathrm{~b}$ \\
Gunny bag & 2517.50 & $2117.40 \mathrm{ab}$ & $1850.39 \mathrm{~b}$ & 12.00 & $15.97 \mathrm{~b}$ & $19.30 \mathrm{~b}$ \\
\hline
\end{tabular}

Means bearing same letter(s) within same column do not differ significantly at $1 \%$ level of significance

DAS $=$ Days after storage

\section{Effect of containers and storage periods on seed colour of French bean at 60 DAS}

Initial seed colour of French bean was white. After 60 days of storage, seed colour of Tin container was more or less same as initial colour, but seeds of Gunny bag changed into fade or brown colour.

From the above study, it was found that 1000 -seed weight was significantly influenced by the containers for all storage periods. Thousand seed weight in a given situation increased with the increase of storage period. The maximum 1000-seed weight was recorded in Gunny bag and the lowest was recorded in Tin container for all storage periods. Thousand seed weight was increased gradually upto 60 DAS higher in Gunny bag might be due to large size of French bean seed which absorbed more moisture from air. Storage container showed significant effect on moisture content for all storage periods. Moisture content increased with the increase of storage periods. Gunny bag resulted in the highest moisture and Tin container resulted in the lowest moisture, which was followed by Polythene bag for all storage periods. Moisture content was increased gradually upto 60 DAS and the highest was in Gunny bag might be due to large size of French bean seed which absorbed more moisture from air. The rate of absorbance was highest in gunny bag because of gunny bag was not air tight container. But tin container and polythene bag were moisture proof so, increasing rate was low in these two containers. Bankole et al. (1999) stored melon seeds in jute and polyethylene bags for 12 months. The moisture content (mc), incidence of visible moldiness (ivm) and germinability of the stored seeds were determined monthly. The mc ranged from 6.1 to $6.7 \%$ in jute and 6.2 to $6.5 \%$ in polyethylene bags. Huda (2001) mentioned that seed kept in metal container had the lowest moisture content followed by those in polythene bag, earthen pot; jute bag and bamboo bin sealed partially or completely. The metal container can restrict 
movement of moisture from ambient atmosphere into the seed better than other containers.

Germination is the most important function of a seed as an indicator of its viability and worth as seed. Germination was significantly influenced by the containers for all storage periods in the study. Germination percentage was decreased with the increase of storage period. Germination percentage was decreased gradually upto 60 DAS in Gunny bag might be due to high moisture and fungi infestation. The highest germination was recorded in Tin container which was statistically similar to Polythene bag and the lowest germination was recorded in Gunny bag for all storage periods. Bankole et al. (1999) stored melon seeds in jute and polyethylene bags for 12 months and determined moisture content (mc) monthly. The mc increased from 6.1 to $6.7 \%$ in jute and 6.2 to $6.5 \%$ in polyethylene bags after 12 months in storage. The germination percentage decreased from $96.3 \%$ to $28.7 \%$ and $45.3 \%$ in jute and polyethylene bags, respectively. Seed rot was statistically influenced by storage container for all storage periods. Seed rot was increased with the increase of storage period. Gunny bag gave the highest seed rot and Tin container gave the lowest seed rot which was followed by Polythene bag for all storage periods. Seed rot was increased gradually upto 60 DAS higher in Gunny bag might be due to high moisture and fungi infestation. Copeland (1976) stated that moisture content had the influential effect on seed storage and high moisture content obviously deteriorated total quality of the stored seed. It has been found that species of Aspergillus and Penicillium are responsible for the deterioration of stored seed of rice, wheat, pulses, oil seeds and different vegetable crops. In the opinion to experts on an average 2-3\% of the total stored seed is damaged by the activities of storage fungi in the country (Fakir, 1989). Khalequzzaman et al. (2003) found that control treatment gave the highest seed rot (31.08\%) of French bean during germination.

Normal and abnormal seedling was significantly influenced by the containers for all storage periods. Normal seedling was decreased with the increase of storage period and abnormal seedling was increased with the increase of storage period. The highest normal seedlings were recorded in Tin container which was followed by Polythene bag and the lowest normal seedling was recorded in Gunny bag for all storage periods. The maximum abnormal seedling was recorded in Gunny bag and the minimum abnormal seedling was recorded in Tin container, which was statistically identical to Polythene bag. Mali et al. (1983) reported that increasing rate of abnormal seedling was higher in seeds of gunny bag, because it was due to high moisture and fungal activities.

Vigour index or seedling vigour was significantly influenced by the containers for all storage periods. Vigour index was decreased with the increase of storage period. The highest vigour index was obtained from Tin container, 
which was followed by Polythene bag and the lowest were obtained from Gunny bag for all storage periods. Vigour index was decreased gradually upto 60 DAS more in Gunny bag might be due to low vigour of seeds for long storage periods, high moisture and fungi infestation. Lin (1999) observed that cucumber seed with $12 \%$ initial moisture content were stored at $70 \% \mathrm{RH}$ and $20^{\circ} \mathrm{C}$ for up to 10 months and germination percentage remained high throughout the storage period, while vigour decreased and electrolyte leakage increased from 6 months of storage.

Storage containers had significant effect on incidence of $F$. oxysporum for all storage periods. Incidence of $F$. oxysporum was increased with the increase of storage period. The highest incidence of $F$. oxysporum was observed in Gunny bag and the lowest incidence was observed in Tin container which was followed by Polythene bag for all storage periods. Khalequzzaman (2004) found that 19.99\% seeds were infected by Fusarium spp. and 19.65\% seeds were infected by Rhizopus sp. in blotter method of French bean seed. Francisco and Usberti (2008) stated that low seed moisture content reduced Alternaria spp. The highest incidence of Fusarium spp. (7.5\%) was occurred at $16.2 \% \mathrm{MC}$ and $35-40^{\circ} \mathrm{C}$ in French bean seed. Penicillium spp. and Aspergillus spp. were predominant and the highest incidences $(80-100 \%$; $20-30 \%$, respectively) were scored at $18.5 \%$ $\mathrm{MC}$ at $30-35^{\circ} \mathrm{C}$ and $13.1-18.5 \% \mathrm{MC}$ at $35^{\circ} \mathrm{C}$, respectively.

Biotic factors like insect and fungi were investigated during the storage period in different storage containers. No insect was found to any storage container for whole storage periods. It was observed that initial seed colour of French bean was white. After 60 days of storage, seeds of Tin container were more or less same as initial colour, but seeds of Gunny bag were changed into fade or brown colour. Fade or brown colour was might be due to increased moisture and fungi infestation. Many parasitic seed borne fungi infect the seed coat causing conspicuous black, brown or grey necrotic discoloration (Neergaard, 1979).

It may be concluded that moisture content, 1000-seed weight, abnormal seedlings, seed rot, fungi association were increased, but germination and normal seedlings were decreased with the increase of storage periods. Among the three containers, Tin container was the best and the Gunny bag was the worst storage containers for French bean seed for upto 60 days of storage.

\section{References}

Ahmad, S. 2001. Environmental effects on seed characteristics of sunflower (Helianthus annuus L.). J. Agron. Crop Sci. 187: 213-216.

Anonymous. 2002. A quarterly publication of the horticultural export development foundation, agricultural services innovation and reform project (ASIRP), Dhaka. Hortex Newsletter 2 (1 \& 2) : 1-2. 
Baki, A. A. and J. D. Anderson. 1973. Vigour determination in soybean by multiple criteria. Crop Sci. 13: 630-633.

Bankole, S. A., B. Ikotun and E. J. Ekpo. 1999. Fungal deterioration of melon seeds stored in jute sacks and polyethylene bags in Ago-Iwoye, Southwestern Nigeria. Mycopathologia 146(3):135-46.

BARI. 1993. Intensive vegetable growing and its utilization. Bangladesh Agricultural Research Institute, Joydebpur, Gazipur. p.245.

Booth, C. 1971. The Genus Fusarium. Commonwealth Mycol. Institute. Kew, Surrey, England. pp. 231 \& 236.

Copeland, L. O. 1976. Principles of Seed Science and Technology. Burgess Pub. Com; Minncapolis, Minnesota. pp. 164-165.

Fakir, G.A. 1989. Seed health test in seed quality control and seed certification. Department of Plant Pathology, Seed Path. Lab. Pub. No. 4. Bangladesh Agricultural University, Mymensingh, Bangladesh. pp. 1-9.

Francisco, F. G. and R. Usberti. 2008. Seed health of common bean stored at constant moisture and temperature. Scientia Agricola 65 (5): 120-123.

Gomez, K. A. and A. A. Gomez. 1984. Statistical Procedures for Agricultural Research. $2^{\text {nd }}$ ed., Intl. Rice Res. Inst., John Willy and Sons, New York, Chichester, Brisbane, Toronto, Singapore. pp. 187-240.

Heydecker, W. 1979. The vigor of seeds-a review. Proc. Int. Seed Test assoc, 34:201209.

HRDP. 1995. Winter Vegetable and Spices Production. Training Manual, Horticulture Research and Development Project (FAO/UNDP/AsDB Project, BDG/87/025) and DAE, BADC, Dhaka. p. 284.

Huda, M. N. 2001. Why quality seed? Reality \& vision, Bangladesh context. BangladeshGerman Seed Development Project, Dhaka, Bangladesh. p. 90.

ISTA, 1999. International Rules for Seed Testing. International Seed Testing Association. Seed Sci. and Technol. 4: 3-177.

Khalequzzaman, K. M. 2004. Biological control of foot and root rot of French bean by using antagonist (Rhizobia). Ph. D. Thesis, Department of Plant Pathology, BAU, Mymensingh, Bangladesh.

Khalequzzaman, K. M., M. K. Uddin, M. A. Rahman, M. A. Rouf and A. K. M. Z. Rahman. 2003. Effect of fungicides in controlling foot and root rot of French bean by seed treatment. Bangladesh J. Agril. Sci. 30 (1): 9-14.

Lin, S. S. 1999. Effect of duration of storage under controlled conditions on mungbean seed quality. Revista do setorde Ceiencies Agrareis 18: 7-16.

Mali, J. B., M. B. Joi and P. A. Shindh. 1983. Fungi associated with chilli seeds. J. Mah. Agril. Univ. 8: 69-71. 
McFadden, W and R. Hall. 1987. Yield response to differential suppression by fungicides of the stem rot phase of bean foot rot. Canadian J. Plant Pathol. 9(3): 246-251.

Neergaard, P. 1979. Seed Pathology, Vol. 1. The Macmillan Press Ltd., London and Basingstoke. p. 839.

Rakhi, S. S. 2000. Key note paper presented on "Strengthening of National Vegetable Seed Production. GCP/BGD/025/BEL and GCP/BGD/028/DEM in the National Seminar on Vegetable Improvement and Seed Production, March 3-4, 2000 at BARI, Gazipur, Bangladesh.

Rashid, M.1999. Shabjir Chash (Bangla). Rashid publishing house, 94, Old DOHS, Dhaka-1206. p. 396.

Singh, R. S. 1982. Plant Pathogens-The Fungi. Oxford \& IBM Publishing Co. New Delhi, India. 564 p. 